Powell, D., Higgins, H. J., Aran, R. \& Freed, A. (2009). Impact of No Child Left Behind on curriculum and instruction in rural schools. The Rural Educator, 31(1), 19-28.

\title{
Impact of No Child Left Behind on Curriculum and Instruction in Rural Schools
}

\author{
Deborah Powell \\ University of North Carolina at Wilmington \\ Heidi J. Higgins \\ University of North Carolina at Wilmington \\ Roberta Aram \\ Missouri State University \\ Andrea Freed \\ University of Maine, Farmington
}

\begin{abstract}
This article examines the influence of the No Child Left Behind Act on the decision making of rural principals and teachers about curriculum and instruction as well as the possible long-term effects on rural education. Data were gathered from 101 rural elementary school principals in Missouri and 76 rural elementary school teachers in Maine. Missouri principals were concerned about losing their autonomy and abilities to be instructional leaders. Maine teachers reported that NCLB benefited some groups of students more than others and that it has a negative effect on student motivation. There were significant changes in instructional time for some subjects and non-instructional time for recess and kindergarten nap time. The most important influence on principals' educational vision for the future and the need for professional development was meeting AYP and raising test scores.
\end{abstract}

"The idea of teaching looks less attractive with NCLB," reported a rural teacher in Maine. When asked how much pressure they felt to raise children's test scores, $42 \%$ of Missouri rural elementary principals respondents either reported, "I worry about keeping my job" or "I worry a lot; it seems impossible."

\section{Introduction}

According to the United States Government Accountability Office (2004), one quarter of the nation's school districts are rural, many in isolated locations with large populations of economically disadvantaged students. Nearly half of these districts have an average of two schools (U.S. GAO, 2004). In these districts, the standardized test scores of a single student could have a greater impact on the academic performance of the entire school than larger urban and suburban school districts. Rural students have the same mobility rate as the national average (U.S. GAO, 1994), but rural children's mobility is almost always related to poverty, and causes a heightened risk for academic failure (Paik \& Phillips, 2002; U.S. GAO, 1994; Fitchen, 1994). Many U.S. rural schools are plagued with declining enrollment and experience difficulty hiring and retaining highly qualified teachers (U.S. GAO, 2004). As a result, many rural schools face more challenges in meeting the provisions of the No Child Left Behind (NCLB) Act of 2001 than non-rural schools.

The purpose of this study was to investigate how the No Child Left Behind (NCLB, 2002) has impacted rural principals' and teachers' decisions about curriculum and instruction and the possible long-term effects on rural education. Numerous reports and studies (United States Government Accountability Office, 2004; National Conference of State Legislatures, 2005; Farmer, Leung, Banks, Schafer, Andrews and Murray, 2006; Zhang, 2008) suggests that NCLB impacts schools in rural communities in ways that are far different from large urban or suburban districts.

The nation's economic future and the success of American democracy are dependent on every student in the nation achieving high levels of success in school. It is critical to understand how instructional decisions made today as a result of NCLB will have far-reaching effects on students as they enter the every-changing workplace of the $21^{\text {st }}$ Century. Rural students make up $22 \%$ of all U.S. public school students (Johnson, 2007); many are already faced with isolation that often limits their exposure to newer 
technologies and a host of experiences available to urban and suburban students.

The authors undertook two studies to better understand the effects of NCLB on rural education, especially concerning educators' instructional and curricular decisions. In Missouri, Powell, Aram and Higgins (2007) surveyed all Missouri elementary public school principals with a written survey. For purposes of this article, we report the data only from rural school principals. In Maine, Freed, with colleagues Julianna Acheson and Rebecca Berger, conducted a study with rural teachers, asking many of the same questions in an open-ended interview created by them in 2007. For this article, we report both studies to show emerging patterns across the two states' rural schools.

\section{Rural School Demographics}

Missouri and Maine, two states with sizable rural populations, have school demographics that parallel rural schools nationwide. Missouri was ranked $14^{\text {th }}$ in the nation and Maine $28^{\text {th }}$ for rural concerns (Johnson, 2007). Missouri has the $15^{\text {th }}$ largest rural student population in the U.S. Forty percent of schools in Missouri are rural and about 30\% of the population of Missouri's students attend a rural school. U.S. Department of Education (2005) reported 253 small rural Missouri school districts in 2005-2006 out of a total of 523 school districts (Missouri Department of Education, 2006). These districts have fewer than 600 students in average daily attendance or the district is located in a county with a total population density of fewer than 10 persons per square mile (Missouri Department of Education, 2008a).

Rural Missouri schools have over a $120 \%$ ten-year increase in rural minority students compared to a $54.9 \%$ increase nationally. This is primarily due to a significant increase in the Hispanic population with many new English language learners entering Missouri schools for the first time. Over $40 \%$ of Missouri's rural children are considered economically disadvantaged (Johnson, 2007).

Almost 53\% of Maine's student population is rural and $56 \%$ of its schools are located in rural areas. U.S. Department of Education (2006) reported 131 rural districts out of a total of 303 in the state in 2006-2007 (Maine Department of Education, 2008). The percentage of Maine's rural students enrolled in special education population ranks among the nation's highest (17\%). Maine also has had a large increase in their rural minority students over a 10-year period (107.5\%). Inequality in the state and local funding revenue per pupil of rural schools versus non-rural schools ranks Maine $17^{\text {th }}$ in the nation (Johnson, 2007).

\section{Background on NCLB}

NCLB mandates that schools make adequate yearly progress in reading and mathematics on state tests in order to continue to receive federal funding. Scores on state tests for all children, including the impoverished, disabled and minority students, must gradually improve until 2014 when $100 \%$ of students in grades three through eight must read and perform in math and science at the proficient level. One student's $3^{\text {rd }}$ grade reading score in a K-6 school of 125 students in rural Missouri will have a far greater impact on the school's AYP than one reading score from one student in St. Louis, Missouri. Schools must report to the community how they are making progress toward this goal. If a school repeatedly fails to make adequate progress toward the goal of $100 \%$ proficiency, there are sanctions ranging from loss of federal dollars to a state takeover of the school. The standards movement has sought to effect massive change in short order, but so far the results have been mixed at best (Wallis, 2008; McCabe, 2006).

A brief timeline of the massive changes being mandated for states and schools between 2002 and 2006 is provided as a backdrop for examining decision and impact of these changes on local rural educators. States' applications for federal funds were approved during the winter and spring of 2003. During the spring of 2004, the first round of competitive Reading First grants was announced for implementation in fall of 2004. The purpose of Reading First was "to apply scientifically based reading researchand the proven instructional and assessment tools consistent with this research - to ensure that all children learn to read well by the end of third grade" (Office of Elementary and Secondary Education, 2008). Reading coaches were hired in Reading First schools and received professional development during the summer of 2004. The second round of grants for Reading First was approved in the spring of 2005. Between the fall of 2003 and the spring of 2005, a review of the professional literature regarding NCLB indicated a lack of support for curricular and instructional changes needed to successfully meet AYP during this early period of implementation.

Elementary principals and teachers across the U.S. are mandated to implement the NCLB law including its requirement to incorporate "scientifically-based" strategies and curricula in reading, mathematics and science instruction. It is interesting to note that the law repeats the words "scientifically based research" over 100 times throughout the text (Learning Point Associates, 2005).

Because elementary school principals are responsible for carrying out state and federal laws, evaluating teachers' instruction, and providing leadership in curriculum in their school, their decisions about curriculum and instruction have the potential to wield great influence over the success or failure of NCLB. Therefore, it is important to assess elementary principals' beliefs about the influences of NCLB on their curriculum and instructional decision-making for their schools. In addition, it is important to understand teachers' beliefs about the effect of NCLB on their teaching and student learning.

Our studies were guided by three goals. The first goal was to determine what curricular and instructional changes rural educators made as a result of the implementation of NCLB 
policies, and the influences on those changes. Questions included with this goal were (a) How has the instructional and non-instructional time been modified as a result of NCLB? (b) Have curricular programs been added or eliminated as a result of NCLB? (c) What was the emphasis of professional development and what influenced the emphasis? (d) What are the prevailing beliefs about the importance of instruction in content areas? (e) How much flexibility do teachers have in implementing curriculum and instruction?

The second goal was to learn if there were changes in the resources available as a result of NCLB and how they benefited students. Questions that pertained to goal two were (a) Are schools using scientifically research based programs? (b) Have new assessments been added? (c) Have new staff members been added since NCLB; if so, in what areas? (d) What resources did principals use for decision making?

Finally, we wanted to give voice to rural educators with regard to both intended and unintended implications of NCLB policies as implemented in rural areas. Therefore, our final question was, How does the NCLB act affect rural principals, teachers and students?

\section{Methodology \\ Participants}

Data were gathered from 76 certified elementary school teachers in rural Maine and 101 rural elementary school principals in Missouri. Maine elementary teachers were interviewed during the spring 2007 semester. Participants formed a convenience sample representing 14 of 16 rural counties in the state. Fifty-six of the teacher-respondents were female. Twenty-six percent of the teachers had taught 5 years or fewer. Hence, these $26 \%$ have taught only under the 2001 NCLB Act. Thirty-two percent of the teachers had a master's degree; $68 \%$ had a bachelor's degree only. Fiftysix teachers (75\%) received their teacher preparation from universities in Maine and 20 had degrees from other colleges and universities.

A survey was sent to all 571 Missouri elementary public school principals during May, 2006. The 101 respondents whose schools were located in rural area were included in this study; $76 \%$ of these principals were in Title I schools. Almost twenty-seven percent of the respondents' schools had $76-100 \%$ of their students on Free and Reduced Lunch (FRL) and $45 \%$ of the respondents' schools had $46-75 \%$ of their students on FRL. Like the national sample of rural schools, most of the districts were small; $55 \%$ had only one school in the district; $14 \%$ had 2 schools and $10 \%$ had three schools. Although the median student population of these rural schools was $301-400$ students, $17 \%$ of the schools had 100 or fewer students. The majority (70\%) of the schools contained both primary and intermediate grades (K-4, K-5 or K-6), but $12 \%$ were $\mathrm{K}-8$ schools, thus having the principal and teachers be concerned with statewide assessments at grades 3-8. Most of these K-8 schools had the smallest student population.

In Missouri, $76 \%$ of the principal-respondents were female. Thirty percent of the principals had a Master's degree; $66 \%$ had a Specialist's degree; and $4 \%$ had a Doctoral degree.

\section{Data Collection Procedures}

Teachers were interviewed by trained studentinterviewers from a small rural university in western Maine (Freed, Acheson \& Berger, 2008). Students received ethnographic interview training as part of their undergraduate degree research coursework. Interviewers followed strict guidelines set forth by the university's Human Subject Review Committee to safeguard the rights of interviewees. Interviewers collected sufficient data for credible and dependable trends to emerge (Lincoln \& Guba, 1985).

Rural elementary principals in Missouri were surveyed regarding their curricular and instructional decisions prior and subsequent to the implementation of NCLB policies in their school. Surveys included demographic items, three of which asked the respondent to identify their school as rural, urban or suburban. One hundred sixty-five surveys were returned, resulting in a $29 \%$ return rate. Of these surveys, 101 of the respondents indicated that their school was identified as a rural elementary school. Twenty-four percent of Missouri's rural elementary school districts participated in the survey.

\section{Instrumentation}

Maine's teachers responded to 8 items gathering demographic data and 8 open-ended questions. Open-ended questions addressed changes in teacher curriculum choices and instructional practices subsequent to NCLB legislation. Additionally, teachers were asked to comment on student benefits of NCLB including student motivation to learn and general teacher opinions of NCLB.

Rural Missouri elementary school principals were surveyed regarding their curricular and instructional decisions prior and subsequent to the implementation of NCLB policies in their school. They responded to 105 items on either a paper survey mailed to their building or an electronic survey, with Internet access provided in the cover letter of the paper survey. Seventeen items addressed principal, district and school demographics including rural, urban or suburban designation; 10 items addressed student achievement; 40 items examined dedicated time allocations during the school day; 25 items addressed principals' curricular, instructional and professional development decisions; 11 items examined principals' decision-making processes; and 2 items addressed issues related to special education. 


\section{Data Analysis Procedures}

Maine teachers' open-ended responses were sorted using emergent categories. Responses to each question were coded and placed into categories identified by an initial sort of all answers to each question. Descriptive techniques were used to determine frequencies and percents for the Missouri principals' demographic data and survey responses. Paired samples t-tests were also calculated on questions pertaining to time allocations of different subject areas during the school day. These statistics were utilized to determine if there were changes in time allocations after the implementation of NCLB. The test for significance was set at the .05 alpha level and Cohen's $d$ was the measure used to calculate effect size.

\section{Results}

The results reported represent rural Missouri principals' situations in the spring, 2006 and rural Maine teachers' attitudes in spring, 2007. It is our belief that some of these results from the principals would be different had the survey been sent out in the spring, 2008. We will discuss this later, and leave the readers to make their own judgments.

\section{Curricular and Instructional Decisions and What Influenced Them}

Instructional time. A comparison of before and after NCLB at both K-3 and grades 4-6 showed significant changes in use of instructional time for teaching reading. A paired samples t-test revealed a statistically reliable difference between time spent on teaching reading (K-3) prior to NCLB (M=80.67 minutes per day, $s=20.31)$ and post NCLB $(M=90.83, s=24.15), t(89)=3.63, p<.001$. The effect size was $d=0.38$ which, according to Cohen (1988), is a small to medium effect size. A significant increase in time was also found for time spent on teaching reading in grades 4-6. Prior to NCLB, time spent teaching reading was 68.01 minutes per day $(s=20.71)$ and post NCLB, the time had increased to 77.56 minutes ( $s=22.88), t(87)=3.73, p<.001$. The effect size was $d=0.4$, or small to medium. This is selfreported data from administrators on "time spent" and likely more accurately represents allocated time rather than actual time spent on instruction. It certainly does not attempt to reflect actual time children were engaged in instruction.

A significant difference was not found for time spent teaching science, mathematics or socials in grades $\mathrm{K}-3$, nor for time spent teaching social studies and mathematics in grades 4-6. Table 1 presents information regarding averages for each content area and grade level band. NCLB did not require the assessment of social studies and science in the spring of 2006, but schools knew that science would be assessed in the coming year at $5^{\text {th }}$ grade level. Because of this, we expected to find an increase in science instruction; however, we found just the opposite. There was a significant decrease in science in grades 4-6 from 50.23 minutes $(s=21.3)$ prior to NCLB and 43.26 minutes $(s=10.4)$ after NCLB, $t(85)=3.61, p<.01$. The effect size was $d=0.39$ or small to medium according to Cohen (1988). These findings were corroborated by the Maine teachers: "We had to adopt a new reading program. The emphasis is on math and language arts; social studies has taken the back burner and science is not strong.” Forty-one (54\%) rural Maine teachers indicated that social studies received less attention and 34 teachers (45\%) reported that science received less emphasis since NCLB. Thirty-one teachers (41\%) reported that math and English received more emphasis. Although we aren't trying to generalize across a wide population, we find it interesting that the comparison of these two sets of data do suggest some common trends in rural schools in these two states.

There were no significant changes reported by Missouri principals in time spent on art, music, and physical education instruction. Maine teachers, however, reported that the arts and electives such as foreign languages, music, health and theatre received decreased emphasis. In one example, a lower elementary school (K-3) no longer offers foreign language instruction to grades $\mathrm{K}-2$. We didn't ask Missouri principals about foreign languages, health, and theatre. We assumed that health was included in science in Missouri and that foreign languages and theatre were not being taught in most rural Missouri elementary schools. We don't know if the Maine teachers were referring to the music and theatre activities that may have occurred in their own classrooms instead of the special times set aside for the art and music instruction with specialists that the Missouri principals referenced.

Non-instructional time. The non-instructional times we examined were nap time in kindergarten and recess at grades K-2, 3-4, and 5-6. These questions were spurred by a comment by Andre J. Hornsby, superintendent of Maryland's Prince George's County Schools as reported in a news analysis by the American School Board Journal (Burrington, 2004), "Nap time needs to go away. We need to get rid of all the baby school stuff they used to do.” Mr. Hornsby's comments were a predictor of the times to come. Prior to NCLB, kindergarteners were allotted an average of 29.33 ( $s=15.8$ ) minutes to nap daily. Post NCLB, this time was reduced to 26.73 ( $\mathrm{s}=14.13), \mathrm{t}(74)=2.82, \mathrm{p}<.01$ with an effect size of $d=.04$. 
Table 1

Mean Differences between Times Spent on a particular Task prior to and After the No Child Left Behind Act

\begin{tabular}{|c|c|c|c|c|c|c|}
\hline \multirow[t]{2}{*}{ Content Area or Activity } & \multirow[b]{2}{*}{$\underline{\mathrm{t}}$} & \multicolumn{2}{|c|}{ Prior to NCLB } & \multicolumn{2}{|c|}{ Post NCLB } & \multirow[b]{2}{*}{$\underline{\mathrm{df}}$} \\
\hline & & $\underline{\mathrm{M}}$ & $\underline{\mathrm{SD}}$ & $\underline{\mathrm{M}}$ & $\underline{\mathrm{SD}}$ & \\
\hline Teaching Reading (K-3) & $3.63^{* * *}$ & 80.67 & 21.31 & 90.83 & 24.15 & 89 \\
\hline Teaching Reading (4-6) & $3.73 * * *$ & 68.01 & 20.71 & 77.56 & 22.88 & 87 \\
\hline Teaching Mathematics (K-3) & 1.77 & 54.61 & 13.99 & 57.30 & 14.58 & 88 \\
\hline Teaching Mathematics (4-6) & 1.48 & 71.08 & 18.96 & 74.30 & 19.02 & 87 \\
\hline Teaching Science (K-3) & 1.26 & 38.60 & 12.77 & 36.74 & 10.61 & 88 \\
\hline Teaching Science (4-6) & $3.61^{* *}$ & 50.23 & 21.31 & 43.26 & 10.40 & 85 \\
\hline Teaching Social Studies (K-3) & 0.82 & 35.33 & 09.36 & 34.50 & 09.12 & 89 \\
\hline Teaching Social Studies (4-6) & 1.74 & 45.17 & 11.39 & 43.26 & 11.13 & 85 \\
\hline Teaching Art (K-3) & 1.93 & 54.29 & 12.94 & 55.27 & 12.57 & 91 \\
\hline Teaching Art (4-6) & 0.45 & 55.28 & 12.09 & 55.45 & 12.05 & 88 \\
\hline Teaching Music (K-3) & 0.58 & 55.28 & 13.49 & 55.45 & 13.46 & 88 \\
\hline Teaching Music (4-6) & 0.82 & 56.08 & 13.74 & 56.42 & 13.64 & 87 \\
\hline Teaching Physical Education (K-3) & 1.35 & 57.13 & 14.63 & 58.15 & 14.80 & 88 \\
\hline Teaching Physical Education (4-6) & 1.14 & 58.62 & 14.58 & 59.13 & 15.06 & 86 \\
\hline Recess (K-2) & $4.90 * * *$ & 37.04 & 12.65 & 32.26 & 11.69 & 92 \\
\hline Recess (3-4) & $4.22 * * *$ & 32.47 & 10.74 & 28.31 & 08.98 & 88 \\
\hline Recess (5-6) & $2.44 *$ & 27.63 & 09.25 & 24.94 & 08.88 & 77 \\
\hline Nap Time & $2.82 * *$ & 29.33 & 15.80 & 26.73 & 14.13 & 74 \\
\hline
\end{tabular}

${ }^{*} \mathrm{p}<.05 . \quad{ }^{* *} \mathrm{p}<.01 . \quad{ }^{* * *} \mathrm{p}<.001$.

The decreased time for recess post NCLB was significant at all three levels grade level bands. Kindergarten through second grade cut recess from 37.04 minutes a day $(\mathrm{s}=12.65)$ to 32.26 minutes $(\mathrm{s}=11.69)$ post NCLB, $\mathrm{t}(92)=4.90, \mathrm{p}<$ .001 with an effect size of $d=0.51$ (medium based on Cohen). For grade 3-4, recess was cut from 32.47 minutes $(\mathrm{s}=10.74)$ to 28.31 minutes $(\mathrm{s}=8.98)$ after NCLB, $\mathrm{t}(88)=4.22, \mathrm{p}<.001$ with an effect size of $d=0.45$. The cuts in recess were also significant for grades 5-6, with 27.63 minutes ( $\mathrm{s}=9.25)$ prior to NCLB, cut to 24.94 minutes $(\mathrm{s}=8.88)$ after NCLB, $\mathrm{t}(77)=2.44, \mathrm{p}<.05$; and effect size $d=0.28$, small to medium based on Cohen (1988).

Length of school day. When asked if the school day had been lengthened due to NCLB, only $4 \%$ indicated that it had. Fifty percent of these respondents, however, indicated that their school day was already longer than the typical 7 hours and $2 \%$ of these rural schools had school days longer than 8 hours, due primarily to busing of high school students to a different district with the same buses used for elementary children.

Changes in school curriculum. Principals indicated that programs had been added due to NCLB, but there was little consistency. The areas most frequently added were writing, special reading and character education, followed by spelling, handwriting, computers and special mathematics. Though adding writing, spelling, special reading and special mathematics were likely a result of NCLB, there was so little consistency that we can't assign much meaning to these results.

There has been considerable concern across the nation that science and social studies instruction were getting short changed for reading and mathematics. We asked rural elementary principals to rate their beliefs about the importance of science and social studies at the primary and intermediate grades using a four-point Likert scale of strongly agree, agree, disagree and strongly disagree. 
Although the majority of respondents disagreed or strongly disagreed, $19 \%$ or 19 rural principals agreed that science is not critical in the primary grades. Only 2 principals or $2 \%$ agreed that science was not critical in the intermediate grades. For social studies, the picture is a little grimmer; $22 \%$ agreed that social studies isn't critical in the primary grades and $4 \%$ strongly agreed. For the intermediate grades, $1 \%$ agrees and $2 \%$ strongly agrees that social studies are not critical in the intermediate grades.

Principals reported that curriculum rotation had been altered as a result of NCLB in $60 \%$ of the reported schools. Textbook adoption cycles were altered as a result of NCLB in $46 \%$ of the schools. We did not ask how these cycles were altered. When teachers in Maine were asked about recent changes they had seen in their district's curriculum, $50 \%$ reported large effects while $37 \%$ reported small effects due to NCLB and 22\% reported no effects. Increased testing was the change mentioned most frequently and viewed most negatively. Teacher comments included, "Students are being tested to death but learning less." "They are just making children learn in order to pass tests but not for the good of learning." "The curriculum is interrupted for the standardized testing."

Changes in professional development. Professional development decisions made by $72 \%$ of the responding rural principals were primarily to assist teachers in meeting AYP and to raise test scores. Only $23 \%$ of the principals indicated that professional development choices were based on teachers' interests and needs, and $16 \%$ were based on district mandates. In each of the indicated school years 2002-2006, Reading was the primary emphasis of professional development (PD) in rural schools by a mean of $73 \%$ across the 4 school years, with a slight dip in emphasis in 2005-2006. Language Arts PD was emphasized by a mean of $42 \%$ of schools across the 4 years. Mathematics PD was emphasized by a mean of $39.36 \%$ of the schools. Technology PD was fourth with a mean of $22.28 \%$ of schools giving this area emphasis; however, our survey did not distinguish between technology as a tool for teachers and use of technology as a learning tool for children. Between the school years 2002-2003 and 20052006, the number of schools having science PD increased from $10.89 \%$ to $14.85 \%$. Social studies PD was consistently lacking, emphasized by a mean of only $5.20 \%$ of the schools over the 4 years.

Flexibility in the curriculum. Benchmarking, a practice that sets expectations for all students to be at a certain level in the curriculum at a particular point in time, is a method used in some schools to make certain that all students are learning the same material. Some schools also refer to this as a pacing guide. Rural principals indicated that $51 \%$ of their schools had implemented benchmarking primarily as a district decision. Over 68\% indicated that they had benchmarks for reading instruction; $34 \%$ for math; $17 \%$ for spelling and language arts; and only $12 \%$ had benchmarks for science and for social studies.
When asked how much flexibility teachers had in making decisions about implementing curriculum, 35\% of the principal respondents answered that, "Teachers have moderate flexibility." The remainder of the respondents were somewhat divided over their responses from having a great deal of flexibility (27\%) to very little flexibility (21\%). Fifty percent of Maine teachers reported that NCLB has had a large effect and is "changing the entire curriculum" and the way they teach. "I teach differently to the standards". Teachers in Maine, bemoaned a loss of "flexibility to be creative" that was replaced by a "focus on reading, writing and math". These teachers perceived the curriculum as narrowing and shifting toward scripted "drill and kill" methods that leave little room for creativity and individualized instruction. "As a result", teachers say, "students are less motivated to learn because they experience less flexibility and more regimentation in instruction. Students don't care and they've become lazier”.

Modes of instruction. A large number of principals (79\%) reported that the preferred method of instruction was a balance of inquiry and direct instruction. Direct instruction was the reported preferred method in $12 \%$ of the schools and inquiry was reported as preferred by only $4 \%$. We did not ask if this had changed as a result of NCLB implementation.

Influences on rural educator's decision making. When asked what influenced their educational vision for the future, $82 \%$ of these rural principals responded "Meeting AYP and raising test scores." On the survey, principals were allowed to name more than one influence, thus the total percentages add to more than 100. "District mandates" were rated as the $2^{\text {nd }}$ most powerful influence, with $33 \%$ of respondents indicating this. When asked what the \#1 short term goal that influenced curricular and instructional decisions, $51 \%$ of the rural principals again ranked "Meeting AYP and raising children's test scores" as their highest short term priority. Nearly one quarter (24\%) ranked "Children's success in future schooling” as their \#1 short term goal. Thirteen percent indicated that the "Quality of teachers in my school" was the \#1 short term goal that influenced their decisions.

We expected there to be a change concerning which long term goal was the \#1 influence on decisions making. However, the top choice remained the same: "Meeting AYP and raising children's test scores" (42\%). The second most highly rated influence was "Children's success in future schooling” (29\%), followed by "Children's development as effective citizens" (15\%).

For schools across the nation, probably the two greatest influences of NCLB on curricular and instructional decisions were (1) the increasing percentage of students scoring at the proficient level on the state assessments each year in all subgroups in order to meet AYP, and (2) the Reading First grants received by selected schools. By spring 2006, 36\% of rural Missouri respondents had applied for a Reading First grant, but only 10\% had received one. Only 
$4 \%$ of these rural schools had been designated as "in need of improvement" according to NCLB, compared to $12 \%$ of schools nationwide in the 2005-2006 school year (National Education Association, 2008). Only 2\% had decreased their student population as a result of parents opting to send their children to another school as allowed by the legislation. In other words, rural Missouri principals, as of 2005-2006 school year, were relatively unaffected by the two major factors that had influenced some schools. Those statistics changed drastically by 2008 with over 55\% of the 368 Title I Missouri schools not meeting AYP and likely to receive some level of sanction during the coming year (Missouri Department of Education, 2008b).

\section{Resources available in rural schools}

Basal textbooks. Rural schools in the Missouri study overwhelmingly used basal textbooks for instruction. In mathematics, 82\% reported textbook use; 65\% reported using social studies textbooks; $61 \%$ used reading basals; and $57 \%$ reported using science basal textbooks. In language arts, about half of the schools did not use a basal text. Fortyfour percent of schools have adopted scientifically researchbased curriculum models in addition to basal textbooks in at least one content area in the past three years.

New staff added. Reading coaches were virtually nonexistent prior to Reading First. Reading First required funded schools to hire a reading coach. Although only $10 \%$ of the Missouri rural school principals reported receiving a Reading First grant, 36\% reported having a reading/literacy coach by spring 2006. Only 6\% reported having a mathematics coach. Eleven percent of the principals said they added special education staff due to NCLB.

Assessments. There was no reported change in the number of standardized tests being administered before and after the implementation of NCLB; however, we didn't ask about the possibility that more grades were being tested. NCLB required schools to change from assessing one grade level at elementary school to assessing grades 3 through 6 in reading and mathematics.

\section{Effects of NCLB on Children, Teachers, and Principals}

Effects on children. Maine teachers explained that they did not feel well-prepared to provide for the instructional needs of children who struggle to learn. They reported that struggling and special needs students are left behind. One fourth of the Missouri principals indicated that more students have been classified for special education since NCLB than before.

Maine teachers disagreed on the impact NCLB had on student motivation. Eleven percent said it had a positive effect, 32\% said it had no effect, and 58\% reported that NCLB has had a negative effect on student motivation. Even if student motivation in general is negatively affected, we can assume that NCLB has had a positive impact on children's test scores in reading and mathematics. We asked the Missouri rural principals if their schools had met AYP in Mathematics and Reading. Mathematics scores were on a steady rise from 2002-2005 because the percentage of schools reported meeting AYP in math increased from $88 \%$, 91\% and 93\%. Seventeen percent of Maine teachers, however, think that NCLB causes stress for children. Some Maine teachers felt that NCLB is unfair to some children and unrealistic for most, though it does make teachers more accountable to student learning. Other teachers said they believe that the overemphasis on testing does not benefit students and it ignores individuals. Sixty-four percent of Maine teachers reported that NCLB benefited some groups of students more than others. In fact, some teachers believed that NCLB has no benefit for any children. As one teacher summed up, "True learning is being replaced by a focus on passing the tests and so students are learning less."

Effects on teachers. In Maine, many teachers reported being "discouraged and want[ing] out" of teaching. "No one wants to work at a school that is rated poorly." "Low performing schools lose experienced teachers to early retirement or to private schools." "Teachers prefer to teach in more affluent school districts”. Participants believe that "new teachers are more prepared!" However, "the idea of teaching looks less attractive with NCLB." "In theory, there are some good ideas, but in practice it is unrealistic or does not work." "It is a great idea and a very good goal, but it is a 'hefty' thing to ask." Forty-four percent of the Maine teachers paint NCLB negatively with descriptors such as: not plausible, too much assessment, overwhelming, too restricting,, frustrating, inadequate, unrealistic, not best for the students extreme, overemphasis on testing, discards lower level students, children aren't learning what they need to know, impractical, ignores individuals, and unfair. One teacher summed up the effects of NCLB on rural Maine teachers, "Frustrations make teachers leave public schools."

Effect on elementary principals. Fifty-eight percent of Missouri rural principals reported no change in the amount of autonomy they felt in making curricular and instructional decisions in their school. Thirty percent felt they had less autonomy in decision-making than before the implementation of NCLB. Fifty-three percent indicated they share autonomy with others and 9\% felt that they have very little autonomy in their instructional and curricular decisions. Only 2\% demoted that they make most of the curricular and instructional decisions in their school.

Forty-three percent of respondents reported that they worry some but do not lose sleep over raising children's test scores. Principals felt most of the pressure coming from district expectations due to NCLB (63\%), and to some degree, the reputation of the school (24\%). Thirty-six percent of these rural principals worry a lot and felt that it is impossible to meet the requirements of NCLB: $6 \%$ of these Missouri rural principals worry about keeping their jobs. 


\section{Discussion}

Elementary school has always been considered the foundation for future learning. Decisions made today about curriculum and instruction in elementary schools have the potential to influence education at other levels, to have longterm effects on students, and could even have an effect on the future of our nation. NCLB Law has the teeth to make wide-scale changes. Rural schools in the past were often slower at making changes; however NCLB has definitely brought rural teachers and principals to action.

\section{Curricular and Instructional Changes}

Reading First required 90 minutes of reading instruction at grades K-3 for schools receiving the grants. Although less than $10 \%$ of the schools had received grants, within two years of implementation of Reading First, rural schools in Missouri had added 10 minutes to their 80 -minute primary reading instruction and 10 minutes to the 68-minute average intermediate (4-6) grades reading instruction. From our observations in schools during this time, we noted that many teachers taught phonics and phonemic awareness separate from reading at a different time during the school day, which may mean that the total time for reading instruction could be even greater than that reported by the principals.

The school day wasn't lengthened, so where did this time come from? Schools in Missouri shaved seven minutes a day from science instruction and three minutes a day from recess at the intermediate grades. This is especially surprising considering all knew that mandated science testing at $5^{\text {th }}$ grade would begin one year later. Science testing results may not have been of concern because they didn't affect the schools' AYP. Primary teachers made cuts in non-instructional areas taking a few minutes from recess and even nap time in kindergarten. What is significant about these results is that science and social studies did not receive significant cuts, even though the states across the nation have reported these content areas have been left behind. Art, music, and physical education remained intact, likely because they are generally taught by a specialist and provide the opportunity for teachers to be released to have their required planning time. In many schools, this is also the time for the reading coach to meet with teachers.

Schools overwhelmingly chose to emphasize reading professional development over other subject areas. Though we recognize that emphasis on reading is important, slighting math and science, two subjects that elementary teachers traditionally are more fearful of and thus teach less effectively, makes little sense if we want children to succeed in all areas and not be left behind in high school and beyond. Leaving out social studies professional development may ultimately lead to lower reading skills because teachers may not know how to teach concepts that become important schema for reading.
Almost $12 \%$ of the schools reported direct instruction which parallels the $10 \%$ of Reading First schools, and $68 \%$ of rural schools have implemented benchmarking where teachers are told by the district what they should be teaching on any particular day. We think it can be safely said that rural schools have approached reading improvement with a structured instructional method. This conclusion is supported by the Maine teachers reporting a shift toward scripted "drill and kill” method.

\section{Changes in Resources}

Basal textbooks allow for uniform instruction, making pacing easier. Missouri rural principals reported $61 \%$ use of reading basal textbooks. All Reading First schools were required to use a basal, accounting for about $10 \%$ of the basal textbook use. Textbooks are more comprehensive and less expensive than purchasing many sets of guided reading books or sets of literature. In Missouri, 24\% of the rural principals responding were not Title I schools, thus giving them more flexibility in their choice of reading instructional materials. This may account for some of the $39 \%$ reporting to not use a basal textbook.

Reading assessments have changed since NCLB, but most changes have occurred after the implementation of Reading First and may not be reflected in these studies. Schools have added staff resources such as reading coaches and special education teachers. The emphasis is definitely a deficit model in which we hold educators accountable for raising the bar, but put resources in place mainly to pull up the bottom.

\section{Effects of NCLB on Rural Students, Teachers, and Principals}

It is a sad state of education when elementary principals' visions of schooling are influenced more by the desire to "meet AYP and raise test scores" rather than by "children's success in future schooling." The influence of AYP and raising test scores on schools is confirmed by the Maine teacher who said that "true learning is being replaced by a focus on passing the tests, and so students are learning less."

Even though principals in rural Missouri reported an increase in the percentage of schools meeting AYP in mathematics, a recent study reported that there have been declines in reading since the implementation of NCLB (Fuller, et al., 2007). Over half of the Maine teachers report that children are negatively affected by NCLB. According to Maine teachers, NCLB is a noble idea; however it is impractical as it has been implemented. The primarily rural teachers feel that NCLB is having an effect opposite of its intended purpose. NCLB is creating achievement differences, increasing the stigma on low-test scoring children and the majority of the Maine teachers interviewed believed that the law unfairly benefited some children over others. 
In Maine, many rural teachers, especially in lowperforming schools, want out of teaching and feel that the profession is looking less attractive to new teachers. The pressures of NCLB has caused many teachers to adopt teaching methods that lack innovation and creativity often leaving teachers to feel that they are unable to use their professional judgment about what's best for their students. NCLB has allowed tests to dictate what is taught in schools regardless of the students' academic and personal needs.

Anthony Cody (2007), a National Board certified teacher and science content coach in Oakland, California reiterates this same sentiment:

As a teacher, I know my students respond when they are encouraged, but when told they are failing and threatened with dire consequences, they tend to shut down, rather than improve. We teachers are no different. We entered this profession to make a difference. We would be far better off if we tapped that passion in a positive direction, instead of operating as if teachers need to be threatened in order to improve.

NCLB is violating teachers' professional norms and values while fostering an increasingly anti-intellectual climate in our nation's schools. The potential number of experienced teachers leaving the profession as soon as they can get out and intelligent young people not entering the teaching profession, means rural schools that already have difficulty finding highly qualified teachers may be heading for a future staffing disaster.

Missouri elementary principals were concerned about losing their autonomy and abilities to be instructional leaders, but they were divided between those not "losing sleep" over NCLB and those who felt it was impossible or even feared for their jobs. If our school leaders were feeling stress in trying to make AYP in 2006, imagine the increase in that stress level as the percentage of students required to meet the proficient level in mathematics and reading reaches the 75\% mark in 2009. The U.S. Department of Education has granted Missouri some reprieve by approving a growth model. "The growth model looks at the academic performance of individual students to determine if they are 'on track to be proficient' within four years. If students who are scoring below the 'proficient' standard in reading or math are making progress and appear likely to achieve proficiency, then they may be counted with the school's other proficient students” (Morris, 2008).

It is essential to consider the long term effects of the curricular decisions that are influenced by NCLB. The current students will be the decision-makers of the future. Will they have the skills and educational preparation to meet the needs of our future society?

\section{References}

Burrington, D. (2004 May). Good-bye to nap time: Spurred by NCLB, elementary schools get serious. American School Board Journal, 6.

Cody, A. (2007, December 14). State schools on collision course with standards. Sacramento Bee, Editorials section, p. B7. Retrieved September 13, 2008 from: http://www.sacbee.com/110/story/566574.html.

Cohen J. (1988). Statistical power analysis for the behavioral sciences. ( $2^{\text {nd }}$ ed.). Hillsdale, NJ: Lawrence Erlbaum Associates.

Datnow, Amanda A., \& Castellano, Marisa. (2000). Teachers' responses to Success for All: How beliefs, experiences, and adaptations shape implementation. American Educational Research Journal, 37, 775-800.

Farmer, T. W., Leung, M-C., Banks, J., Schaefer, V., Andrews, B. \& Murray, R.A. (2006 Summer). Adequate yearly progress in small rural schools and rural lowincome schools, The Rural Educator. 27(3), 1-7.

Fitchen, J. (1994). Residential mobility amongst the rural poor. Rural Sociology, 59(3), 416-436.

Freed, A., Acheson, F., \& Berger, R. (2008, January). Maine Teacher Reflections on No Child Left Behind. Paper presented at the Association for Science Teacher Education International Conference, St Louis, MO.

Fuller, B., Wright, J., Gesicki, K., \& Kang, E. (2007). Gauging growth: How to judge No Child Left Behind? Educational Researcher, 36(5), 268-278.

Johnson, J. (2007, October). Why rural matters 2007: The realities of rural education growth. Arlington, VA: Rural School and Community Trust. Retrieved June 25, 2008 from: http:/www.ruraledu.org/site/apps/s/

link.asp?c=beJMIZOCIrH\&b=3508815

Learning Point Associates (2005, October). Using scientifically based research in schools. The Center for Comprehensive School Reform newsletter. Retrieved November 15, 2008 from: http://www.centerforcsri.org/files/

TheCenter_NL_Oct05.pdf.

Lincoln, Y. S., \& Guba, E. G. (1985). Naturalistic Inquiry. Thousand Oaks, CA: Sage Publications.

Maine Department of Education (2008). School System contact directory. Retrieved July 12, 2008 from: http://mainegov-images.informe.org/education/ eddir/pdffiles/medschss.pdf

McCabe, M. (2006, January 5). State of the states.

Education Week, 25(17), 78-90.

Missouri Department of Education (2006). 2005-2006 Report of the public schools of Missouri, Table 12. Retrieved July 12, 2008 from: http://www.dese.mo.gov/schooldata/AnRept06.pdf. 
Missouri Department of Education (2008a). Small, rural school achievement program and rural and low-income school program. Retrieved July 9, 2008 from website: http://www.dese.mo.gov/divimprove/fedprog/financialma nagement/REAPinstructions07-08.pdf.

Missouri Department of Education (2008b, August 1). Middle-Schoolers Make Strong Gains on 2008 MAP Tests; More Schools and Districts Do Not Meet "AYP" Targets. Missouri Department of Elementary and Secondary Education News Release, 42(54).

Morris, J. (2008, June 26). DESE wins approval to use

"Growth Model” for schools to meet NCLB requirements. Missouri DESE News Releases. Retrieved September 14, 2008from: http://dese.mo.gov/news/2008/growthmodel.htm.

National Conference of State Legislatures (2005). Delivering the promise: State recommendations for improving No Child Left Behind. Washington, D.C.

National Education Association (2008). Adequate yearly progress (AYP) status, 2005-06 to 2007-08. Retrieved September 1, 2008 from: http://www.nea.org/nclbaction/states/images/ayp.pdf

No Child Left Behind (NCLB) Act of 2001, Pub. L. No. 107-110, 115 Stat. 1425 (2002, January 8) Retrieved April 12, 2008 from:

http://www.ed.gov/policy/elsec/leg/esea02/index.html.

Office of Elementary and Secondary Education. (2008, January 14). Reading First. Washington, D.C.: United States Department of Education. Retrieved July 2, 2008 from:

http://www.ed.gov/programs/readingfirst/index.html.

Paik, S. \& Phillips, R. (2002). Student mobility in rural communities: What are the Implications for Student Achievement? Naperville, IL: North Central Regional Educational Laboratory.
Powell, D., Aram, R. and Higgins, H. (2007). The impact of the No Child Left Behind Law on elementary school principals' curriculum and instructional decisions, unpublished raw data.

United States Department of Education (2005) SRSA Eligibility Spreadsheets for Fiscal Year 2005/School Year 2005-2006. Retrieved July 12, 2008:

http://www.ed.gov/programs/reapsrsa/eligible05/ index.html

United States Department of Education (2006) SRSA Eligibility Spreadsheets for Fiscal Year 2006/School Year 2006-2007. Retrieved July 12, 2008 from: http://www.ed.gov/programs/reapsrsa/eligible07/me.xls.

United States Government Accountability Office (U.S. GAO). (1994). Elementary school children: Many change schools frequently, harming their education (GAO/HEHS Publication No. 94-45). Washington, DC: U.S. Government Printing Office.

United States Government Accountability Office (U.S. GAO). (2004). No Child Left Behind Art: Additional assistance and research on effective strategies would help small rural districts. Washington, DC: U.S. Government Printing Office.

Wallis, C. (2008, June 8). No child left behind: Doomed to failure. Time, in partnership with CNN. Retrieved June 26, 2008 from: http://www.time.com/time/nation/article/ 0,8599,1812758,00.html

Zhang, Y. (2008, June 10). Some perspectives from rural school districts on the No Child Left Behind Act. Washington, D.C.: Center for Educational Policy. 